\title{
Analyses of the vertical and temporal distribution of sulfate-reducing bacteria in Lake Aha (China)
}

\author{
M. Y. Wang · X. B. Liang $\cdot$ X. Y. Yuan •
}

W. Zhang $\cdot$ J. Zeng

Published online: 23 November 2007

(C) Springer-Verlag 2007

\section{Erratum to: Environ Geol}

\section{DOI 10.1007/s00254-007-0787-6}

Unfortunately, an error occurred in the author's line. The following is the correct corresponding author:

X. B. Liang $(\bowtie)$

e-mail: liangxiaobing@vip.skleg.cn

The online version of the original article can be found under doi:10.1007/s00254-007-0787-6.

M. Y. Wang · X. B. Liang $(\bowtie) \cdot$ W. Zhang $\cdot$ J. Zeng

State Key Laboratory of Environmental Geochemistry, Institute of Geochemistry,

Chinese Academy of Sciences,

Guiyang 550002, China

e-mail: liangxiaobing@vip.skleg.cn

M. Y. Wang $\cdot$ X. Y. Yuan Department of Clinical Lab, Weihai Municipal Hospital,

Weihai 264200, China

e-mail: mingyi_wang@hotmail.com 